\title{
Characteristics of the Homonymic Ambiguity Resolution in Preschool Children
}

\author{
Hee Kwon, Kyunghee Jung \\ Department of Speech and Language Pathology, Graduate School of Rehabilitation and Welfare, Yongin University, Yongin, Korea
}

\author{
Correspondence: Kyung Hee Jung, $\mathrm{PhD}$ \\ Department of Speech Language Rehabilitation, \\ Yongin University, 134 Yongindaehak-ro, Cheoin- \\ gu, Yongin 17092, Korea \\ Tel: $+82-31-8020-2864$ \\ Fax: +82-31-8020-3075 \\ E-mail: 1012jkh@hanmail.net
}

Received: July 5, 2019

Revised: August 9, 2019

Accepted: August 20, 2019

This work is based on a part of the first author's master's thesis from Yongin University.

\begin{abstract}
Objectives: This study purposed to examine differences in ability to resolve homonymic ambiguity among children aged 3 to 5 . Methods: A total of 30 typically developing preschool children aged 3 to 5 participated in this study, and each age group had 10 children. Results: The study results are summarized as follows: first, the number of children who comprehended homonymic ambiguity was significantly different between 3- and 5-yearold children, as well as between 4- and 5-year-old children. Second, the total number of attempts to resolve homonymic ambiguity was significantly different between 3 and 5 years old as well as between 4 and 5 years old. The success rate of resolving homonymic ambiguity was also significantly different between 3 and 5 years old as well as between 4 and 5 years old. Third, the colloquial language resolution rate among the homonymic ambiguity resolution types was significantly different between 3 - and 5-year-old children as well as between 4- and 5-year-old children. However, the resolution rate that involved the use of both colloquial language and gestures was not different between the groups. Fourth, the use of deictic and iconic gestures, which are gesture types used in the case of resolution through the use of both colloquial language and gestures, was not significantly different between the groups. Although the statistics did not show significant difference, 3 years old often used deictic gestures, and 4 years old frequently used deictic and iconic gestures, and 5 years old used iconic gestures relatively frequently. Conclusion: Based upon the results mentioned above, it appeared that the ability to comprehend and resolve homonymic ambiguity develops at the age of 4 and 5 . And the number of attempts by 5 years old decreased, and their success rate increased.
\end{abstract}

Keywords: Homonyms, Homonymic ambiguity, Deictic gesture, Iconic gesture
우리가 일상생활에서 사용하는 많은 언어표현들 중에는 다양한 맥락에서 사용되는 중의적인 표현이 흔하게 발생한다. 이러한 중의 적인 표현은 어휘적 모호성(ambiguity)을 포함하게 되는데, 어휘적 인 수준에서 여러 의미를 가지고 있는 낱말인 다의어(polysemy)나 동음이의어(homonym)가 포함된다. 동음이의어(homonym)는 두 개의 어휘의 발음과 철자가 동일하게 나타나지만 각각 서로 다른 의 미를 갖는 단어범주이고, 다의어는 기존의 의미에 새로운 의미가 함께 공존하고 있는 단어들을 말한다. 그런데 다의어의 경우 발음 과 철자가 동일한 여러 개의 단어들로 간주할 수도 있으므로 넓은 의미에서 보면 동음이의어에 해당한다고 볼 수 있다(Jang, 2000). 이러한 동음이의어와 다의어의 의미적인 유사성이 있는지 없는지
에 따라 분류될 수 있다.

동음이의어나 다의어는 모두 단어에 포함된 여러 가지 의미를 이 해하고 있다는 것을 전제로 하고 있을 뿐 아니라 이 의미들 중에서 문맥에 적절한 의미를 선택하여 문장 전체의 의미파악이 이루어진 다는 점에서 상위언어적 능력의 하위범주에 해당한다(Moon, 2010). 중의적인 어휘가 포함된 문장의 경우 문장의 정확한 의미를 전달 하기 위해서는 어휘적 모호성에 대한 해석이 매우 중요하게 작용한 다. 상위언어능력(metalinguistic)은 언어사용자가 언어 자체에 대 해 생각하고 판단하고 조작할 수 있는 능력으로 학령전기부터 이 에 대한 인식능력이 발달하지만 학령기가 되어서야 탈중심성이 발 달하여 언어의 의미와 언어적 정확성에 주의를 기울이며 처리가 가 
능하게 된다. 또한, 학령기에는 문자 그대로의 의미가 아닌 비유적 언어의 사용능력이 발달함으로써 의사소통 상황에서 정보를 더욱 생생하고 효과적으로 전달하기 위해 사용될 수 있다.

이러한 동음이의어의 어휘적 모호성은 기존 연구에 의하면 약 4 세경부터 감지가 가능하다고 보고되고 있다(Backscheider \& Gelman, 1995; Peters \& Zaidel, 1980). 또한 3-5세 아동들을 대상으로 한 동음이의어 연구에서는 3 세 아동들도 드물지만 동음이의어 모 호성 해소를 위한 시도(35\%)를 하고 있었으며, 4 세 아동들의 경우 도상적인 제스처를 사용하여 동음이의어의 모호성을 해소하려는 시도(49\%)가 가장 빈번하게 나타났다고 보고하였다(Kidd \& Holler, 2009). 이러한 연구결과를 토대로 Doherty (2004)는 4세 이전의 아동에게 어휘적 모호성이 포함된 문장의 해석은 상위언어적 지식 의 어려움과, 맥락단서를 활용하여 의미연결을 하는 데 어려움에서 비롯되었다고 해석하였으며, 먼저 습득한 우세의미 이외의 열세의 미의 혼동을 동음이의어 습득 과정의 어려운 원인으로 제시하였 다. 아동이 충분한 어휘를 갖고 있더라도 동음이의어를 이해하는 데 요구되어지는 단어와 참조물 사이 관계를 형상화하는 데 필요 한 상위언어학적 의식을 갖고 있지 않아 4 세 이전의 아동들은 모호 성 과제를 수행하기가 어렵다는 것이다(Doherty, 2004).

동음이의어가 활용적으로 발달하게 되는 시기는 학령기인데 (Smith Cairns, Waltzman, \& Schlisselberg, 2004; Wankoff \& Smith Cairns, 2009), 학령기 아동들은 학령전기 아동들과는 달리 어휘 의 양적인 측면뿐 아니라 추론을 통한 동음이의어 이해 등과 같은 어휘의 질적인 측면에서의 발달이 이루어지는 시기이다. 이러한 능 력은 또한 아동들의 읽기에 중요한 변인이 된다(Kim, 2010). 어휘적 모호성은 학령기 아동들의 읽기와 관련이 있는데, 그중 특히 읽기 이해와 밀접한 관련이 있다. 초등학교 저학년이 되면 상위언어능력 의 일부인 어휘적·구조적 탐지능력이 발달하기 시작하여 학년이 올라갈수록 향상된다는 연구결과가 있다(Moon, 2010; Smith Cairns et al., 2004). 이러한 과정은 읽기를 통해 새로운 어휘를 습 득하는 것과 연관되는데, 새로운 어휘 중 한 단어에 여러 뜻이 있는 동음이의어를 보다 정확하게 이해하고 습득하게 된다. 학령기 아동 의 대상으로 동음이의어와 읽기이해의 상관관계를 연구한 Wankoff 와 Smith Cairns (2009)는 모호성 문장에서의 동음이의어 이해 과 제가 초등 저학년의 읽기이해를 예측하는 유의한 변인이며 읽기 및 읽기준비 훈련에 사용될 수 있다고 하였다. 또한 초등학교 1-3학년 아동들을 대상으로 한 종단적 연구에서는 동음이의어 능력과 읽기 이해와의 높은 상관관계를 보고하였다(Smith Cairns et al., 2004).

동음이의어나 다의어의 어휘적 모호성 이해능력에 대한 국내연 구는 언어장애를 동반한 집단과 일반아동 집단 간의 비교연구를 중
심으로 이루어져 왔으며, 발달적 특성을 다룬 연구는 제한적이다. Lee와 Lee (2006)는 4-6세 일반아동과 단순언어장애 아동의 어휘적 모호성이 포함된 문장이해능력을 살펴보았는데, 모든 집단 아동들 이 개별어휘수준과 문장수준에서 우세의미의 처리가 어느 정도 가 능하다고 보고하였다. Kim HY (2014)는 초등학교 저학년 아동을 대 상으로 어휘적 중의성 이해능력을 살펴본 결과 열세의미의 경우 1 학 년 시기에 급격한 발달을 보이다 2,3 학년 시기가 되면 안정적 발달양 상을 보인다고 하였다. 또한 초등 3,6 학년의 어휘적 중의성 발달을 연구한 Moon (2010)은 3학년이 중의성에 대한 이해정확도에서 6학 년에 비해 유의하게 낮은 수행력을 보였다고 하였다. 한편 초등 $1,3,5$ 학년을 대상으로 다의어에서의 어휘적 중의성 이해능력을 살펴본 Kang (2018)은 1학년과 3 학년 시기의 다의어 이해능력이 발달하고 3 학년에서 5 학년 시기에 안정적 발달양상을 나타난다고 보고하였다. 반면, 어휘적 모호성에 대한 국내연구들은 주로 언어장애를 겪 고 있는 경도지적장애 아동, 다문화가정의 아동, 읽기부진 아동, 단 순언어장애 아동들의 동음이의어나 중의어가 포함된 문장의 이해 에 관한 연구를 중심으로 진행되었다(Cho, 2006; Jang, Jeong, \& Hwang, 2014; Kang, Hwang, \& Lim, 2013; Kim, 2010 ; Ko, Choi, \& Hwang, 2010; Kwak, Hwang, \& Jung, 2015; Lee \& Lee, 2006, 2007; Shin, 2011; Um, 2013). 다문화가정 아동을 대상으로 한 연구에서 는 다문화가정 아동이 비다문화가정 아동들에 비하여 문화적-환 경적으로 습득할 수 있는 어휘의 양이 비교적 적고, 이로 인하여 동 음이의어 습득에 취약한 조건임을 제시하였다(Jang et al., 2014; Kwak et al., 2015). 음독(decoding)과 언어이해에 어려움을 보이는 학령기 읽기부진 아동들을 대상으로 한 연구에서는 동음이의어나 다의어 처리 과정에서 읽기부진 아동들이 단어와 단어들 간에 개 념을 이해하는 데 오류가 있음을 시사하였다(Kim, 2010; Ko et al., 2010). 또한, 정상아동들에 비하여 언어발달 속도가 느린 학령전기 단순언어장애 아동들을 대상으로 한 연구에서는 단순언어장애 아 동들이 일반아동에 비해 느린 열세의미 처리와 제한적인 관계적 정 의하기 출현을 나타내며, 동음이의어의 의미를 처리할 때 우세의미 단어보다 열세의미 단어 정의에 어려움이 있음을 시사하였다(Lee \& Lee, 2006, 2007). 이와 비슷하게 인지적 어려움으로 언어발달이 지체되는 학령기 지적장애 아동들을 대상으로 한 연구에서도 지 적장애 집단 아동들이 동음이의어 어휘의 우세·열세의미 정의하 기에 어려움을 보였다고 보고하였다(Um, 2013). 지금까지 살펴본 기존 선행연구들의 결과에 의하면 어휘의 의미와 관련하여 어려움 이 있는 아동들이 동음이의어 발달에도 어려움이 있다.

이러한 동음이의어의 발달에 대한 여러 연구들을 종합해 보면 학 령기에 동음이의어의 발달이 더욱 활발히 이루어지나 동음이의어 
의 모호성에 대한 인식은 학령전기부터 가능하다는 것을 알 수 있 다. 하지만 지금까지 국내의 어휘적 모호성에 관련된 연구들은 정의 하기, 의미적 관련성 판단 과제, 문장제시의 형식으로 연구가 진행되 어 왔을 뿐 아니라 주로 학령기 아동들을 중심으로 한 연구들이 대 부분을 차지하고 있다. 또한, 국내 언어치료 분야에서 이루어진 동 음이의어에 관한 연구들은 주로 학령기 언어장애 아동들을 대상으 로 한 구어사용 위주 연구들이 대부분이다. 동음이의어의 모호성 에 대한 탐지능력이 나타나는 시점인 학령전기 아동을 대상으로 한 연구는 몇몇 연구에 제한적으로 다루어지고 있다(Lee \& Lee, 2007).

기존의 어휘적 모호성에 관련된 연구들은 학령기 아동들을 대 상으로 하여 구어발달에 초점을 맞추어 진행된 연구들이 대부분 이다. 하지만 초기 언어습득 과정에서 제스처는 부족한 언어능력 을 보완하고 청자에게 보다 정확한 표현을 전달하기 위한 수단으로 사용되며 언어발달을 예측하고 촉진하는 수단으로 알려져 왔다. 제스처는 크게 지시적 제스처(deictic gesture)와 표상적 제스처 (representational gesture)로 나눌 수 있다. 지시적 제스처는 언어기 이전에 나타나며, 요구나 서술하기 맥락에서 대상을 가리키거나 청 자의 관심을 끌기 위한 목적으로 아동의 부족한 언어능력을 보완 하면서 의사소통 의도를 전달하기 위한 보조수단으로 가리키기, 보여주기 등의 유형이 있다(Capirci, Iverson, Pizzuto, \& Volterra, 1996). 표상적 제스처는 특정 대상에 대한 고정적 의미로 사용되는 것으로 관습적 제스처의 지시(conventional gesture)와 도상적 제 스처(iconic gesture)로 구분된다. 일상생활에서 관습적으로 사용 되는 고개 젓기 등의 제스처는 관습적 제스처에 해당하며, 이 외에 대상의 특징을 도상적으로 표현하여 대상에 대한 의미를 쉽게 떠 올릴 수 있는 것으로 '새'를 의미하기 위해 양손을 펄럭이는 행위 등 은 도상적 제스처에 해당한다. 초기 비언어적 수단으로 사용되었던 지시적 제스처는 점차 언어적 수단으로 대체되면서 언어발달이 이 루어지게 되지만 아직까지 부족한 언어능력은 상대방에게 의미적 정보를 전달하기 위한 보조수단으로서 지속적으로 중요한 역할을 하게 된다. 특히 두 낱말 조합으로 의미관계를 발달시키는 과정에 서 제스처가 의미정보를 보완하는 수단으로 함께 사용되고, 구어 적으로 두 낱말의 의미관계를 표현하기 이전의 전조단계로 '제스처 +구어'의 형태가 발달한다(Acredolo \& Goodwyn, 1988). 구어적 의사소통 능력이 발달하면서 아동이 사용하던 제스처는 점점 줄 어들게 되는데 Iversion과 Goldin-Meadow (2005)는 이러한 제스 처의 기능을 '전이장치(transitional device)'라고 하며 제스처가 초 기 구어발달을 촉진한다고 하였다. 이러한 제스처의 기능은 발화 의 길이가 증가하는 3 세에서 5 세 사이의 아동의 구어발달 과정에 서도 찾아볼 수 있다. 이 시기 아동들은 구어와 함께 제스처의 사
용이 함께 증가하게 되는데, 이때 사용하는 도상적 제스처(iconic gesture)는 후기 언어발달 및 인지발달에 중요한 역할을 한다(Mayberry \& Nicoladis, 2000). 인지적인 부담이 있는 과제수행 과정에 서 아동은 구어로 자신이 알고 있는 개념지식을 충분히 설명하는 데 제한이 있기 때문에 이를 보완하기 위한 제스처의 사용이 늘어 나게 된다는 것이다.

국외의 학령전기 동음이의어 발달연구 중, 충분히 발달하지 않 은 구어를 보완하기 위하여 동음이의어 모호성 해결 시 구어뿐 아 니라 제스처 사용을 함께 본 연구가 있다(Kidd \& Holler, 2009). 이 연구는 3-5세 아동을 대상으로 어휘적 모호성 해결에 대한 발달적 특성을 알아보기 위해 동음이의어 짝이 포함되도록 구성한 짧은 이야기를 듣고 어떻게 그 이야기를 청자에게 회상하여 전달하는가 를 살펴보았다. 또한 이때 아동이 사용한 구어뿐 아니라 제스처, 그 리고 구어와 제스처의 혼합 유형을 함께 살펴봄으로써 모호성을 인지하고 이해하는지, 모호한 어휘를 전달할 때 언어적 제한을 제 스처로 보완하면서 모호성을 해결하기 위한 어떤 전략을 사용하는 지를 분석하였다. 연구 결과, 3 세 아동도 드물지만 지시적 제스처 (deictic gesture)를 사용하여 어휘적 모호성을 해결하려는 시도를 하며, 4 세가 되면 어휘적 모호성 해결능력이 더 발달하는데 이때 도상적 제스처(iconic gesture)사용이 가장 많이 나타났다가 5 세가 되면 언어적 설명능력이 발달하면서 도상적 제스처의 사용이 4 세 에 비해 줄어든다고 하였다.

본 연구에서는 이러한 선행연구를 바탕으로 어휘적 모호성에 대 한 인식능력이 출현하는 3 세 아동부터 학령전기 아동의 동음이의 어에 대한 어휘적 모호성 해결능력에 대한 발달적 특성을 살펴보 고자 한다. 또한 이를 위해 구어뿐 아니라 제스처를 어떻게 사용하 고 있는지도 알아보고자 한다. 이를 위해 본 연구에서 설정한 연구 문제는 다음과 같다.

첫째, 동음이의어 모호성 해결 설명 시 동음이의어 모호성 이해 수와 동음이의어 모호성 해결수가 집단 간에 차이가 있는가?

둘째, 동음이의어 모호성 해결 시 총 시도수와 성공률이 집단 간 에 차이가 있는가?

셋째, 동음이의어 모호성 해결 설명 시 사용한 구어 및 제스처 유 형에 차이가 있는가(구어, 구어+제스처, 지시제스처, 상징제스처)?

\section{연구방법}

\section{연구대상}

본 연구의 대상은 인천, 경기지역 내 어린이집. 유치원에 재원 중 인 만 $3,4,5$ 세 아동들을 대상으로 다음과 같은 사항을 고려하여 
Table 1. Characteristics of age and vocabulary

\begin{tabular}{lccccc}
\hline & $\begin{array}{c}3 \text { years } \\
(\mathrm{N}=10)\end{array}$ & $\begin{array}{c}4 \text { years } \\
(\mathrm{N}=10)\end{array}$ & $\begin{array}{c}5 \text { years } \\
(\mathrm{N}=0)\end{array}$ & $F$ & Scheffe \\
\hline Age $(\mathrm{mo})$ & $42.10(3.70)$ & $53.40(4.12)$ & $67.70(3.86)$ & $108.548^{*}$ & $3<4<5$ \\
REVT-R & $37.20(15.72)$ & $43.70(12.75)$ & $60.20(5.49)$ & $9.592^{*}$ & $3,4<5$ \\
\hline
\end{tabular}

Values are presented as mean (SD).

REVR-R=Receptive \& Expressive Vocabulary Test-Receptive (Kim, Hong, Kim, Jang, \& Lee, 2009).

${ }^{*} p<.05$.

선정하였다. (1) 생활연령이 만 3 세 0 개월-만 5 세 11 개월 사이의 아 동, (2) 수용·표현어휘력검사(Receptive \& Expressive Vocabulary Test, REVT; Kim, Hong, Kim, Jang, \& Lee, 2009)의 수용어휘력 검 사 점수가 표준편차 - $1 \mathrm{SD}$ 초과인 아동, (3) 주양육자나 담임교사로 부터 신경학적·인지·사회성·정서·운동기능에 이상이 없다고 보고 된 아동, 연구에 참여한 각 연령집단 아동의 평균연령과 수용어휘 점수는 Table 1에 제시되어 있다.

\section{검사도구}

대상자 선정도구: 수용·표현어휘력검사(REVT)

모든 대상 아동들에게 수용·표현어휘력검사(REVT) 중 수용어 휘 검사를 실시하여 언어능력 발달 지연 여부를 선별하였고, 검사 결과 $-1 \mathrm{SD}$ 를 초과하는 아동을 대상자로 선정하였다.

\section{본 검사도구}

\section{검사어휘선정}

본 연구의 초기 어휘로 선정된 어휘들은 기존 논문(Jang et al., 2014; Kim, 2010; Lee \& Lee, 2007; Shin, 2011)에서 사용된 동음이 의어들과 교육과학기술부(Ministry of Education and Science Technology, 2013)에서 출판된 3-5세 연령별 누리과정 의사소통영역에 서 사용된 어휘로 총 41 개가 수집되었다. 이 중에서 언어재활사들 을 대상으로 타당도 검사를 통하여, $3,4,5$ 세의 아동들이 이해 가 능하고, 동음이의어의 두 가지 의미를 모두 알 수 있는 친숙한 6 쌍 의 고빈도 어휘로 최종 선정하였다. 선정된 어휘는 Appendix 1에 제시하였다.

\section{이야기·구성 및 그림자료 만들기}

본 실험은 Kidd와 Holler (2009)의 연구에서 사용한 이야기 내 용을 참고하여 어휘 및 이야기 내용을 한국판으로 수정하여 총 4 문장으로 이루어진 이야기를 작성하였다. 어린 연령의 아동들을 고려하여 1-3번째 이야기는 단문 형태의 문장을 사용하였으며, 마 지막 4 번째 이야기만 동음이의어 대립을 위하여 복문을 사용하였
다. 1 번째 이야기는 배경을 제시하고, 2 번째와 3 번째 이야기는 각각 하나의 동음이의어를 제시하였다. 마지막 4 번째 이야기는 2 번째와 3 번째에 하나씩 제시된 동음이의어를 대립시켜 구성하였다. 아동 들의 주어 혼동을 막기 위하여 주인공을 친구로 통일하였다. 또한 선행연구를 참고로 이야기를 들려줄 때와 아동이 이야기를 산출 할 때 함께 제시될 이야기 그림자료를 제작하였는데 이야기를 들으 며 집중할 수 있게 동음이의어와 관련된 대상 외에 다른 대상들을 넣지 않고 간결하게 그렸다. 이야기와 그림의 예는 Appendix 2에 제 시하였다.

타당도

과제의 타당도는 1,2 급 언어재활사자격증을 소지한 언어재활사 16 명을 대상으로 타당도 검증을 실시하였다. 언어재활사를 선정한 이유는 본 연구의 대상 아동들이 검사문항의 어휘들을 알고 있다 는 전제로 제작이 되었기 때문에 언어재활사를 대상으로 타당도를 검증받았다. 문항의 검증은 총 5 점 척도로, 매우 적합함, 적합함, 보 통, 부적합함, 매우 부적합함으로 평가하도록 하였다. 이 중 아동이 표현하기 어려운 추상적인 어휘를 제외하고, 동음이의어 어휘의 평 균이 3.5점 이상인 어휘들을 선정하였다. 선정된 어휘에 대한 어휘 타당도검사 결과는 4.05 이다.

\section{연구절차}

예비검사 실시

본 검사에 앞서 검사 절차의 타당성을 알아보기 위하여 무선표 집(random sampling)으로 3-5세 사이의 아동 8명을 대상으로 예 비검사를 실시하였다. 예비검사는 수용어휘검사 점수가 표준편차 $-1 \mathrm{SD}$ 초과인 아동을 대상으로 실시하였다. 예비검사 결과 보조자 가 아동의 회상이야기를 듣고 동음이의어에 대한 인지 및 해결능 력을 알아보기 위한 질문 과정이 좀 더 세분화되어야 할 필요성이 인식되었다. 이에 따라 Kidd와 Holler (2009)의 연구에서는 아동이 이야기를 마친 후 보조자가 아동의 마지막 질문을 다시 말하면서 두 단어가 어떻게 다른지를 물어보도록 되어 있었는데 이 과정에 서 바로 다른 것을 설명하기 어려워 하고 어떻게 답해야 할지 모르 는 경우 우선 두 단어가 같은지 다른지를 먼저 물어 이해 여부를 확 인한 후 모호성 해결을 유도하는 질문을 시작하는 방식으로 질문 절차를 일부 수정하였다. 또한 모호성 해결을 위한 질문 과정에서 도 아동이 다르다고 했을 때 '어떻게 다른지’ 묻고, 아동이 하나의 의미만 해결했을 때 다른 의미는 같은 것이지, 다른 것인지, 다르면 어떤 의미인지를 단계적으로 나눠서 질문하는 등 좀 더 세분화된 절차를 적용하였다. 
본 검사 실시

선별검사

본 검사에 앞서 연구자가 아동의 어휘력이 정상발달하는지 알아 보는 선별검사로 수용·표현어휘력검사(REVT) 중 수용어휘검사 를 $1: 1$ 상황에서 실시하였다. 검사 결과 $-1 \mathrm{SD}$ 초과 아동 38 명을 대 상으로 본 검사를 실시하였으나, 아동의 검사 거부나, 집중력 저하 등의 이유로 본 검사가 이루어지지 않은 아동 8 명은 제외되었다.

\section{동음이의어 모호성 해결 검사}

본 실험은 Kidd와 Holler (2009)의 연구방법을 참고하여 수정하 여 진행하였다. 본 검사는 아동이 재원 중인 어린이집. 유치원의 조 용한 방 또는 아동의 집에서 연구자 1 명과 보조자 1 명이 함께 실시 하였다. 본 검사에 앞서 연구자는 검사절차 및 실시방법, 채점방법 에 대하여 숙지하고, 보조자는 검사절차에 대하여 훈련을 받은 후 본 검사에 투입되었다.

실험이 시작되기 전 연구자와 보조자가 함께 참석한 자리에서 연 구자는 그림카드 제시 전에 아동에게 "OO이가 이야기를 잘 듣고 나서, 다른 선생님(보조자)한테 그대로 이야기를 해 주어야 해.”라 고 강조하여 검사 절차에 대해 설명하였다. 설명을 마친 후 보조자 는 퇴실을 하게 하고 연구자와 아동은 보드판을 사이에 두고 마주 보고 앉아 그림카드를 보드판에 붙여주면서 해당하는 이야기의 문장을 들려주었다. 아동에게 이야기를 모두 들려준 후, 아동이 다 시 듣기를 요청하였을 때 이야기를 다시 들려주었다. 아동이 들려 준 이야기 회상이 가능하다고 판단되었을 때, 보조자를 입실시켜 아동으로 하여금 이야기를 회상할 수 있도록 유도하였다. 이때 이 야기 그림의 위치는 아동만 볼 수 있도록 하고, 보조자는 보드판의 그림을 볼수 없도록 설치하였다.

아동이 보조자에게 이야기를 설명한 후, 보조자는 "배와 배가 어떻게 다르니?” 같은 동음이의어의 모호성을 해소할 수 있는 질문 을 하였다. 아동이 4 번째 그림에서 동음이의어에 대한 모호성을 설 명하지 못할 경우, 아동에게 동음이의어의 모호성을 해소할 수 있 는 질문을 하여 유도하였다. 이때 아동의 대답을 동음이의어 해소 시도수로 카운트하였다. 이때 동음이의어 해소 시도수는 제한을 두지 않았다. 아동에게 질문을 하여 시도를 촉진하였음에도 불구 하고 아동의 반응이 없거나 실패한 반응이 연속해서 나온 경우, 동 음이의어의 해소에 어려움이 있는 것으로 간주하고 아동을 격려한 후, 보조자는 방 밖으로 나가고 나서 두 번째 이야기를 반복하여 시 행하였다. 아동의 음성과 제스처를 캠코더 영상으로 녹화하고, 녹 화 후 일주일 이내에 전사하여 분석하였다.

\section{자료분석}

본 실험은 Kidd와 Holler (2009)의 연구자료 분석절차를 참고하 여 본 연구의 목적에 맞게 수정하여 분석하였다.

\section{동음이의어 이해}

동음이의어 모호성 해결 과제 중 보조자가 아동에게 두 단어가 동일한 의미를 갖는지에 대한 질문의 반응을 통하여 동음이의어 이해수를 분석하였다. 아동이 동음이의어 이야기를 듣고 동음이의 어 모호성이 있다고 답한 경우는 2점, 아니라고 답하는 경우는 1점 을 받았다. 따라서 총 6 개의 문항에서 모호성을 이해하는 경우 총 12점을 받게 된다.

\section{동음이의어 모호성 해결}

동음이의어 모호성 해결 과제 중 보조자의 질문을 통하여, 아동 이 동음이의어 모호성을 ‘구어' 또는 '구어+제스처'의 유형으로 정 반응한 경우를 분석하였다.

\section{시도수}

시도수는 보조자가 아동에게 동음이의어 모호성을 해결할 수 있게 질문을 유도하여, 아동의 반응을 세었다. 아동의 동음이의어 모호성 해결 시도의 양은 제한하지 않았는데 그 이유는, 동음이의 어의 모호성 해소에 어려움이 있다고 판단될 때까지 보조자가 질 문을 유도하기 때문이었다.

\section{시도성공률}

각 아동마다 성공 시도수를 총 성공 시도수로 나누어 백분율로 분석하였다.

\section{구어 및 '구어+제스처' 설명 유형}

본 연구에서 아동들이 동음이의어 모호성 해결을 위하여 나타 난 양상으로는 구어의 사용 없이 제스처만 표현한 아동은 관찰되 지 않았으며, 구어만 사용하거나 구어의 보완기능으로 제스처를 함 께 사용한 유형은 관찰되었다. 하지만, 구어의 대체기능으로 사용 된 제스처는 관찰되지 않았다. 아동이 사용한 제스처의 유형은 지 시적 제스처(deictic gesture)와 도상적 제스처(iconic gesture)가 나 타났다. 본 연구에서는 아동이 동음이의어의 모호성을 해결하기 위해 사용한 유형별 백분율을 계산하여 비교하였다. 이는 아동마 다총시도수와성공수가 달랐기 때문이다. 
구어+지시적 제스처(deictic gesture)

구어 설명과 지시적 제스처를 동반하여 나타나는 경우로 구어적 인 설명과 함께 직접적으로 사물이나 신체부위를 가리키며 표현한 경우를 '구어+지시적 제스처'로 구분하였다. 실험 중 보조자의 명 료화 요구에도 아동이 구어와 지시적 제스처를 사용하여 지속적 으로 그림판의 그림을 가리키는 경우에는 동음이의어 모호성 해소 시도를 세지만, 이는 동음이의어 해결에 실패한 것으로 간주되었다.

\section{구어+도상적 제스처(iconic gesture)}

구어 설명과 도상적 제스처를 동반하여 나타나는 경우로 구어적 인 설명과 함께 사물의 형태나 성질을 표현한 경우를 '구어+도상적 제스처'로 구분하였다. 실험 중 보조자의 명료화 요구에도 아동이 도구의 사용이나 형태와 관련이 없는 도상적 제스처를 사용하는 경우에는 동음이의어 모호성 해소 시도를 세지만, 이는 동음이의 어 해결에 실패한 것으로 간주되었다.

본 검사가 실시 된 38 명의 아동 중, 4 번째 그림의 이야기에서 동 음이의어의 모호성을 명확하게 설명한 30 명의 샘플만을 분석하였 다. 본 실험 중 이야기가 시도되지 않거나, 동음이의어 모호성 해소 에 대한 질문에 대답을 회피하였던 8명의 샘플은 제외하였다. 동음 이의어 모호성 해결 시도 및 시도성공 여부에 대한 분석기준은 Appendix 3에 제시하였다.

\section{자료의 통계처리}

모든 자료는 SPSS version 18.0 프로그램을 사용하여 통계분석 을 실시하였다. 연령별로 나눈 세 집단의 동음이의어 모호성 해결 수와 구어해결률, 성공률, 지시제스처율, 상징제스처율은 집단별 평균분석을 사용하였고, 집단 간 차이를 알아보기 위하여 일원분 산분석 $(p<.05)$ 을 실시하였다. 또한, 동질성 검증에서 개수가 적고,

Table 2. Kruskal-Wallis of comprehension for ambiguity of homonyms

\begin{tabular}{lccccc}
\hline & $M$ & SD & $x$ & $d f$ & $F$ \\
\hline $\begin{array}{l}\text { Comprehension for ambiguity } \\
\text { of homonym }\end{array}$ & 10.17 & 2.76 & 8.51 & 2 & $0.01^{*}$ \\
\hline${ }^{*} p<.05$. & & & & & \\
\hline
\end{tabular}

Table 3. ANOVA of the number of disambiguations of homonyms

\begin{tabular}{lrrrr}
\hline Factor & \multicolumn{1}{c}{ SS } & $d f$ & MS & $F$ \\
\hline Between groups & 82.40 & 2 & 41.20 & $0.01^{*}$ \\
Within group & 215.60 & 27 & 7.99 & \\
Total & 298.00 & 29 & & \\
\hline
\end{tabular}

${ }^{*} p<.05$.
등분산 가정이 성립되지 않은 동음이의어 이해 개수와 총 시도수 에서는 세 집단 비모수검정(Kruskal-Wallis)을 사용하여 집단 간 의 차이를 알아보았다.

\section{신뢰도}

신뢰도는 총 대상 아동의 $20 \%$ 에 해당하는 6 명 아동의 전사자료 에 대해서 연구자와 제 2 채점자의 채점 결과 사이의 일치율을 구하 였다. 제 2 채점자는 본 연구의 목적과 내용을 충분히 숙지하고 있는 제 2 저자이다. 올바른 채점을 위해 시도 및 성공기준에 대한 조작적 정의 내용을 숙지하고 채점에 대한 훈련을 시행한 후 독립적으로 채점하였다. 그 결과 두 연구자 간 신뢰도는 동음이의어 이해수 $100 \%$, 모호성 해결수 $97.2 \%$, 시도수 $91.7 \%$, 성공률 $97.2 \%$, 제스처 해결률 $100 \%$, 구어해결률 97.2\%, '구어+제스처' 해결률 $94.4 \%$ 로 나타났다.

\section{연구결과}

\section{연령 단계별 동음이의어 모호성 이해 및 해결능력}

만 3-5세 집단 간 모호성 이해수의 차이를 알아보기 위하여 Kruskal-Wallis를 실시한 결과는 Table 2 와 같고, 동음이의어 모호성 이해수는 집단 간 유의한 차이가 났다. 또한, 동음이의어 모호성 이 해수에 대한 집단 간 차이를 알아보기 위해 Mann-Whitney U-test 를 실시한 결과 3 세와 5 세 집단 $\left(U_{(17)}=72.00, z=-2.82, p=.05\right), 4$ 세 와 5 세 집단 $\left(U_{(22.5)}=77.50, z=-2.44, p=.15\right)$ 로 유의한 차이 $(p<.05)$ 가 나타났다.

만 3-5세 집단 간 동음이의어 모호성 해결수의 차이를 알아보기 위하여 일원분산분석을 실시한 결과는 Table 3과 같다. 또한, 세 집 단 간의 차이를 알아보기 위하여 Schéffe를 실시한 결과 3세와 5세 집단 $\left(F_{(1,18)}=.01, p<.05\right)$ 에서만 유의한 차이 $(p<.05)$ 가 나타났다.

Table 4. Kruskal-Wallis of the number of disambiguation attempts

\begin{tabular}{cccccc}
\hline & $M$ & $S D$ & $\chi$ & $d f$ & $F$ \\
\hline Disambiguation attempts & 24.77 & 13.09 & 9.18 & 2 & $0.01^{*}$
\end{tabular}

${ }^{*} p<.05$.

Table 5. ANOVA of rate of success for disambiguation

\begin{tabular}{lrrrr}
\hline Factor & \multicolumn{1}{c}{ SS } & $d f$ & \multicolumn{1}{c}{ MS } & \multicolumn{1}{c}{$F$} \\
\hline Between groups & $17,565.38$ & 2 & $8,782.69$ & $0.00^{*}$ \\
Within group & $14,783.03$ & 27 & 547.51 & \\
Total & $32,348.40$ & 29 & & \\
\hline$*<05$ & & & &
\end{tabular}




\section{연령 단계별 동음이의어 모호성 해결 총 시도수와 성공률}

만 3-5세 집단의 동음이의어 모호성 해결 총 시도수의 차이를 알 아보기 위하여 Kruskal-Wallis를 실시한 결과는 Table 4와같다. 동 음이의어 모호성 해결 총 시도수가 집단 간 유의한 차이가 있는 것 으로 나타났고, 동음이의어 모호성 해결 총 시도수에 대한 집단 간 차이를 알아보기 위해 Mann-Whitney U-test를 실시한 결과 3세와 5 세 집단 $\left(U_{(13.5)}=68.50, z=-2.80, p=.05\right), 4$ 세와 5 세 집단 $\left(U_{(18.5)}=73.50\right.$, $z=-2.40, p=.02)$ 으로 유의한 차이 $(p<.05)$ 가 나타났다.

만 3-5세 집단의 동음이의어 모호성 해결성공률의 차이를 알아 보기 위하여 일원분산분석을 실시한 결과는 Table 5 와 같다. 세 집 단의 동음이의어 모호성 해결성공률에 유의한 차이가 나타났고, 집단 간의 차이를 알아보기 위하여 Schéffe를 실시한 결과 3세와 5 세 집단 $\left(F_{(1,18)}=.00, p<.05\right)$ 과 4 세와 5 세 집단 $\left(F_{(1,18)}=.001, p<.05\right)$ 에 유의한 차이 $(p<.05)$ 가 나타났다.

\section{연령 단계별 동음이의어 모호성 해결시도 유형(구어, 구어+ 제스처, 지시제스처, 도상적 제스처)}

각 연령집단의 아동들이 동음이의어의 모호성을 해결을 시도하
거나 해결을 했을 때 사용한 구어 및 제스처, ‘제스처+구어' 유형을 분류하였으나 제스처만 사용한 경우가 관찰되지 않아 구어사용률 과 '구어+제스처' 사용률에서만 집단 간 차이를 살펴보았다. 또한 아동이 사용한 제스처 유형을 지시적 제스처와 도상적 제스처로 나눠서 전체 제스처 사용수에 대한 백분율을 살펴보았다. 이에 대 한 기술통계와 일원분산분석 결과는 Table 6과 같다.

세 집단 간의 동음이의어 모호성 해결 유형 구어 해결시도율과 '구어+제스처' 해결시도율, 구어해결률은 연령이 높아질수록 사용 률이 증가하는 것으로 나타났으며, '구어+제스처' 해결률의 경우 3 세에서 4 세 사이는 늘어났으나 5 세 집단에서는 줄어드는 경향이 나 타났는데 이 중 구어 해결시도율에서만 연령집단별 차이가 유의하 였다. Schéffe 사후검정 결과 3 세와 5 세 집단 $\left(F_{(2,18)}=.0, p<.05\right)$ 과 4 세 와 5 세 집단 $\left(F_{(2,18)}=.001, p<.05\right)$ 에 유의한차이 $(p<.05)$ 가 나타났다. 또한 전체 사용 제스처에 대한 두 가지 유형의 제스처 사용률을 살펴본 결과 지시적 제스처는 3 세와 4 세 사이는 증가하였으나 5 세 의 경우 사용률이 줄었으며, 세 연령대 중 가장 낮은 사용률을 보여 주었다. 반면 도상적 제스처의 경우 3 세 집단에서는 아무도 사용하 지 않았으나 4 세 이후 사용률이 늘어나는 경향을 보여주었고, 5 세

Table 6. Types of disambiguation

\begin{tabular}{|c|c|c|c|c|c|}
\hline & Age group & $\mathrm{N}$ & $\mathrm{M}$ & SD & $F$ \\
\hline \multirow[t]{4}{*}{ Rate of disambiguation attempts by speech only (\%) } & 3 years & 10 & 26.52 & 7.66 & \multirow{4}{*}{$14.728^{*}$} \\
\hline & 4 years & 10 & 32.44 & 6.46 & \\
\hline & 5 years & 10 & 76.25 & 7.06 & \\
\hline & Total & 30 & 45.07 & 5.70 & \\
\hline \multirow[t]{4}{*}{ Rate of disambiguation attempts by speech+gestures (\%) } & 3 years & 10 & 0.50 & 1.58 & \multirow{4}{*}{1.476} \\
\hline & 4 years & 10 & 4.10 & 7.20 & \\
\hline & 5 years & 10 & 6.54 & 11.54 & \\
\hline & Total & 30 & 3.71 & 80.30 & \\
\hline \multirow[t]{4}{*}{ Rate of disambiguation by speech only (\%) } & 3 years & 10 & 58.33 & 24.22 & \multirow{4}{*}{4.441} \\
\hline & 4 years & 10 & 62.50 & 28.12 & \\
\hline & 5 years & 10 & 86.67 & 14.27 & \\
\hline & Total & 30 & 69.17 & 25.54 & \\
\hline \multirow[t]{4}{*}{ Rate of disambiguation by speech+gestures (\%) } & 3 years & 10 & 0.83 & 0.83 & \multirow{4}{*}{1.197} \\
\hline & 4 years & 10 & 9.17 & 5.62 & \\
\hline & 5 years & 10 & 6.67 & 3.69 & \\
\hline & Total & 30 & 5.56 & 2.27 & \\
\hline \multirow[t]{4}{*}{ Rate of deictic gestures (\%) } & 3 years & 10 & 10.00 & 32.62 & \multirow{4}{*}{2.282} \\
\hline & 4 years & 10 & 32.86 & 47.16 & \\
\hline & 5 years & 10 & 2.50 & 7.91 & \\
\hline & Total & 30 & 15.12 & 34.53 & \\
\hline \multirow[t]{4}{*}{ Rate of iconic gestures (\%) } & 3 years & 10 & 0.00 & 0.00 & \multirow{4}{*}{1.723} \\
\hline & 4 years & 10 & 17.14 & 36.76 & \\
\hline & 5 years & 10 & 27.50 & 44.80 & \\
\hline & Total & 30 & 14.88 & 34.29 & \\
\hline
\end{tabular}

${ }^{*} p<.05$. 
에 가장 사용률이 높게 나타났다. 하지만 이러한 기술통계 결과에 대한 집단별 차이는 통계적으로 유의하지 않았다.

\section{논의 및 결론}

본 연구에서는 36-71개월의 아동들을 대상으로 동음이의어 모 호성 해결능력에 차이가 있는지 알아보았다. 연구 결과, 동음이의 어 모호성 이해수와 해결수는 모두 3 세와 4 세 집단 간 차이는 없었 으며, 5 세 집단과의 차이가 유의하게 나타났다. 집단 간에 차이가 난 이유는 3 세 집단과 4 세 집단의 동음이의어 모호성에 대한 이해 수는 평균 9.3개로 동일하게 나타나 두 연령 간 차이가 거의 없는 것 으로 나타났으나 5세 집단의 경우 평균 11.9개(SD .32)로 총 검사어 휘수가 12 개임을 고려할 때 거의 천정점을 보여줬고, 집단 내 아동 들 간 편차도 줄어들었기 때문이다. 이러한 결과로 볼 때 동음이의 어에 대한 이해능력은 3 세경부터 관찰되며 5 세경에 이해능력이 가 파르게 증가함을 알 수 있었다. 또 해결수의 경우 3 세 아동 평균 7.2 (SD 2.97), 4세 아동 평균은 8.6 (SD 3.67)으로 나타났으나 5세의 경 우 11.2 (SD 1.55)로 나타나 이해수와 마찬가지로 5세 아동에게서 증가추세가 가파르게 나타났기 때문인 것으로 해석된다. 이러한 결 과는 4 세까지 비우세 의미에 대한 일관된 습득이 어렵다는 Doherty (2004)의 연구결과를 지지해 주고 있으며, Kidd와 Holler (2009)의 3 세 집단과 4 세 집단이 5 세 집단에 비하여 동음이의어 모호성 해결 을 하지 못하였다는 결과와도 유사하다. 4 세와 5 세 아동들을 대상 의 문장 내 동음이의어 판별 과제를 수행능력을 비교하는 Smith Cairns 등(2004)의 연구에서도 4 세와 5 세 집단 간의 유의미한 차이 를 보였다. 이러한 선행연구와 본 연구의 결과를 통해 통계적으로 는 3 세 집단과 4 세 집단의 동음이의어 모호성 이해수와 해결수에 차이는 없으나 이해 및 해결 가능한 평균어휘수에서는 4 세 집단이 3 세 집단 평균수행력이 증가하는 경향으로 보인다는 점을 알 수 있 었다. 하지만 5 세에 이르러서야 동음이의어에 대한 이해 및 모호한 의미를 해결하는 능력이 증가한다는 점은 동음이의어 모호성 이해 와 해결이 4-5세에 발달한다는 선행연구 결과와 유사하다. 이는 동 음이의어를 이해하고 문맥 내에서 모호성을 해결하기 위해서는 문 맥에 두 가지의 의미 중에서 문맥의 흐름에 적합한 의미를 판단해 야 하는 상위언어능력이 요구되는데 구어발달과제를 해결하는 데 집중되는 시기인 3-4세 아동의 경우 어려운 과제이기 때문이다. 또 한 어려운 의미를 처리하는 데 문맥적 단서를 활용하거나 문맥에 적합하지 않은 의미를 억제하는 기능의 발달이 충분히 이루어지지 않은 시기라는 점도 생각해 볼 수 있다(Doherty, 2004). 하지만 본 연구에서는 3,4 세 아동들도 같은 소리로 들리지만 의미가 다르다
는 의미적 차이를 문맥 내에서 감지하고, 이의 차이를 해결하기 위 한 전략을 발달시키고 있다는 점을 살펴보았다는 점에서 의미론 발 달에 대한 시사점을 제시하고 있다.

다음으로 동음이의어의 모호성을 해결하기 위한 시도수와 시도 수에 대한 해결성공률을 살펴본 결과 두 변인 모두 통계적으로 유 의하게 연령집단 간 차이가 있었으며, 역시 마찬가지로 두 변인 모 두 3,4 세가 같은 집단에 5 세가 다른 집단으로 분류되었다. 연구 결 과 동음이의어 모호성 해결을 위한 시도는 3,4 세 집단이 5 세 집단 보다 많이 하였고, 5 세 집단이 동음이의어 모호성 해결을 위한 시 도를 적게 한 것으로 나타났으나 시도에 비해 동음이의어 모호성 해결성공률은 5 세 집단이 높게 나타났다. 기술통계 결과에서 평균 값을 비교해 봤을 때 3 세 집단의 경우는 시도수도 적고, 성공률 또 한 세 집단 중 제일 낮게 나타났으며, 4 세 집단이 3 세 집단보다 시도 수가 조금 더 적고, 상대적으로 성공률이 높은 경향을 보였다. 전체 적으로 연령이 증가함에 따라 동음이의어 모호성 해결을 위한 시도 는 줄어들고(3세 31.6회, 4세 28.1회, 5세 14.6회), 성공률(3세 27.29\%, 4세 $37.02 \%, 5$ 세 $82.79 \%$ )은 증가하고 있는데 3 세와 4 세 사이의 증 감률에 비해 4 세와 5 세 간의 증감률이 2 배 이상으로 나타나고 있 다는 점을 알 수 있었다. Kidd와 Holler (2009)의 연구에서도 3세 집단과 4 세 집단의 동음이의어 모호성 해결성공률의 차이가 유의 하게 나타나지 않았으나, 3 세 집단보다 4 세 집단의 동음이의어 모 호성 해결성공률이 높다고 나타나 본 연구 결과가 위의 선행연구 를 지지해 주고 있다. 이러한 결과는 3 세 집단과 4 세 집단의 아동들 은 동음이의어 모호성에 대해 완벽하게 인식하는 데 어려움이 있 고, 이해한 동음이의어 모호성을 정교하게 해결하는 데 어려움이 있음을 시사한다.

마지막으로 동음이의어 모호성 해결 및 해결을 위해 시도한 전략 으로 구어뿐 아니라 부족한 언어능력을 보완할 제스처 사용까지 함께 살펴보았는데, 본 연구 결과에서는 제스처만 단독으로 사용 한 경우는 어느 연령대에서도 관찰되지 않았고, 구어와 '구어+제스 처' 유형만 분석대상에 포함되었다. 이는 다른 유형에 비해 사용횟 수가 적고, 연령이 높아질수록 줄어들기는 하지만 모든 연령대에서 제스처만 사용하여 모호성을 해결하려는 시도가 관찰되었다는 Kidd와 Holler (2009)의 연구결과와는 다르다. 이는 본 연구에서는 3 세 아동부터 대상에 포함되기는 했지만 수용어휘능력이 정상발 달하는 아동들을 대상으로 하였고, 과제에 사용된 어휘가 선행연 구에 비해 일상생활에 자주 사용하는 어휘 중심으로 구성되었다 는 점에서 구어를 보완할 제스처 사용의 기회가 적었을 수 있기 때 문이라고 사료된다. 이는 '구어+제스처'의 유형도 전 연령대에서 매 우 낮은 빈도로 사용하고 있어 제스처의 보완 역할의 필요성이 전 
체적으로 적었을 것으로 보인다. 또한 제스처 사용이 풍부한 선행 연구와 우리나라의 문화적 차이 역시 영향을 미쳤을 것으로 해석 해 볼수 있다. 추후 연구에서는 제스처의 사용 기회를 고려해 보는 것도 의미가 있을 것으로 사료된다.

한편 동음이의어 모호성 해결 및 해결을 시도한 유형 중 구어 해 결시도율에서 연령집단 간 통계적으로 유의한 차이가 나타났는데 사후검정 결과 3 세와 5 세 집단, 4 세와 5 세 집단이 다른 집단으로 분류되었다. 이렇듯 구어 해결시도율이 3 세 집단과 4 세 집단에 비 하여 5세 집단이 높게 나타났다는 본 연구는 Kidd와 Holler (2009) 와 연구결과를 지지해 주고 있으며, 이들 연구 결과는 3-4세 집단은 5 세 집단에 비해 동음이의어 모호성을 구어로 해결하는 데 제한이 있음을 시사한다. 하지만 '구어+제스처' 해결시도율, 구어해결률, '구어+제스처' 해결률에서는 집단 간 유의미한 차이가 나타나지 않 았다. 그런데 동음이의어 모호성 해결유형 중 3 세 집단은 구어해결 률이 낮게 나타나고(평균 58.32\%) '구어+제스처' 해결률(평균 $0.83 \%$ ) 도 낮게 나타났지만, 4 세 집단에서는 동음이의어 모호성을 해결하 기 위한 제스처의 보완적인 사용률이 늘었으나(평균 9.17\%) 5 세 집 단(평균 $6.67 \%$ )에서는 제스처를 사용해 모호성을 해결한 비율이 줄어드는 경향을 보이고 있고, 전체 총 제스처 사용도 5 세에 다소 줄어드는 경향이 있었다. 이는 3 세 집단에 비해 4 세 집단에서는 구 어해결이 어려운 점을 제스처를 보완적으로 사용하여 해결하려는 시도가 늘어나지만 5 세 집단은 구어가 발달함에 따라 제스처의 보 완 없이도 구어로 해결이 가능해지기 때문에 제스처 사용률이 떨 어진 것으로 해석할 수 있다.

또한 본 연구에서는 각 연령집단의 아동들이 사용한 제스처 유 형을 좀 더 구체적으로 살펴보았는데 지시적 제스처와 도상적 제스 처 두 가지 유형 모두 사용률에서 집단 간 차이가 나타나지 않았다. 이는 전체적으로 제스처 사용빈도가 낮았기 때문이라고 사료된다. 그런데 아동들이 사용한 제스처의 수와 두 가지 유형의 사용률을 연령집단별로 살펴보면, 3 세 집단의 경우는 구어로 표현하기 힘든 부분들은 그림이나 자신의 신체부위를 가리키는 지시적 제스처를 사용하여 동음이의어 모호성을 해결하려 하는 모습이 1 회 관찰되 었다. 반면 4 세 집단의 경우 지시적 제스처의 사용과 더불어 기능 이나 특성을 표현한 도상적 제스처를 사용하여 구어적 설명의 제 한을 보완하려는 경향이 나타났다. 이는 도상적 제스처가 출현하 기 전에 지시적(deictic) 제스처를 빈번하게 사용한다는 Kim HN (2014)의 연구와 24-47개월의 아동들이 지시적 제스처의 사용률 이 높고, 30 개월 이후에 도상적(iconic) 제스처의 사용이 높아진다 는 Ahn, Bang과 Lee (2010)의 연구를 지지해 주는 결과이다. 이 연 구에서는 또한 5 세 아동 집단에서도 제스처를 사용하였는데, 4 세
에 비하여 제스처 사용률이 낮아졌으며, 4 세 아동 집단과는 달리 도상적 제스처 사용률이 지시적 제스처 사용률보다 높게 나타났 다. 이는 보완적인 제스처를 사용하지 않고도 충분히 구어로 동음 이의어 모호성 해결을 하는 것이 가능하기 때문이다. 이러한 결과 는 2 세 6 개월-4세에 걸쳐 도상적 제스처에 대한 인식능력이 발달하 고, 4세 6개월-5세 아동의 도상적 제스처 이해 및 산출능력이 이전 연령대에 비해 높게 나타났다고 보고한 Park (2013)의 연구와, 연령 이 증가됨에 따라 제스처 사용은 감소하고, 구어사용이 증가한다는 Lee (2011)의 연구를 뒷받침해 주는 결과이다. Kidd와 Holler (2009) 의 기존 연구와는 달리 본 연구에서 제스처 사용률이 떨어지지만 구어가 발달함에 따라 제스처의 사용률이 낮아지는 것은 일치한 다. 이러한 차이는 제스처를 많이 사용하는 서양의 문화적 배경과 우리나라의 문화적 차이에서 비롯된 것으로 해석해 볼 수 있다. 하 지만 전반적으로 제스처 사용수가 적고 연령집단별 아동수가 적어 제스처 사용에 대한 본 연구 결과를 일반화해서 해석하는 데는 무 리가 있어 해석에 주의가 필요하다. 추후 더 많은 아동을 대상으로 제스처 사용의 발달적 특성을 좀 더 깊이 있게 살펴볼 필요가 있다. 하지만 본 연구에서 동음이의어의 모호성 해결능력을 살펴볼 때 구어뿐 아니라 제스처 사용도 함께 봄으로써 좀 더 어린 아동을 대 상으로 이러한 특성을 살펴볼 수 있었다는 점에 의의가 있었다.

본 연구 결과 동음이의어 모호성 이해와 해결능력은 4-5세에 주 로 발달하는 것을 알 수 있었고 연령이 늘어남에 따라 동음이의어 해결을 위한 총 시도수는 줄어들고 해결성공률이 높아짐을 알 수 있었다. 또한 4 세 이전 아동들도 동음이의어의 모호성을 이해하고 있으며 이를 해결하는 능력이 있음을 알아보았다는 점에 임상적 의 의가 있다. 이러한 연구 결과는 동음이의어 이해능력에 대한 초기 발달특성을 고려한 어휘 평가 및 중재에 활용될 수 있을 것으로 사 료된다.

\section{REFERENCES}

Acredolo, L., \& Goodwyn, S. (1988). Symbolic gesturing in normal infants. Child Development, 59(2), 450-466.

Ahn, S. J., Bang, H. J., \& Lee, S. H. (2010). The change in the ratio of gesture utilization in 2-3 years old children: focusing on iconic gestures. Korean Journal of Developmental Psychology, 23(1), 33-50.

Backscheider, A. G., \& Gelman, S. A. (1995). Children's understanding of homonyms. Journal of Child Language, 22(1), 107-127.

Capirci, O., Iverson, J. M., Pizzuto, E., \& Volterra, V. (1996). Gestures and words during the transition to two-word speech. Journal of Child Language, 
23(3), 645-673.

Cho, H. (2006). Polysemy comprehension and type analysis of children with hearing impairment (Master's thesis). Dankook University, Yongin, Korea.

Doherty, M. J. (2004). Children's difficulty in learning homonyms. Journal of Child Language, 31(1), 203-214.

Iverson, J. M., \& Goldin-Meadow, S. (2005). Gesture paves the way for language development. Psychological Science, 16(5), 367-371.

Jang, B. A. (2000). Etude sur les criteres de distinction entre homonymie et polys emie: Analyse d'un corpus (Master's thesis). Kyung Hee University, Seoul, Korea.

Jang, J., Jeong, M., \& Hwang, M. (2014). Comprehending and defining homonyms in school-aged children from multicultural families. Communication Sciences \& Disorders, 19(1), 71-79.

Kang, E. S. (2018). Study on understanding polysemy frequency used in elementary school textbooks of the 1st, 3rd, and 5th grades (Master's thesis). Yongin University, Yongin, Korea.

Kang, H. J., Hwang, M., \& Lim, J. A. (2013). The comprehension of homonym in children with poor comprehension skills. Korean Journal of Learning Disabilities, 10(10), 161-176.

Kidd, E., \& Holler, J. (2009). Children's use of gesture to resolve lexical ambiguity. Developmental Science, 12(6), 903-913.

Kim, H. N. (2014). Characteristics of gestures produced in referential communication of school-aged children with mild intellectual disabilities (Master's thesis). Dankook University, Yongin, Korea.

Kim, H. Y. (2014). Lexical ambiguity literacy of students in lower grades at elementary school (Master's thesis). Daegu University, Gyeongsan, Korea.

Kim, S. H. (2010). Comprehension ability of ambiguity sentences using homonyms assignments of low-grade elementary school students with poor reading ability (Master's thesis). Ewha Womans University, Seoul, Korea.

Kim, Y. T., Hong, G. H., Kim, K. H., Jang, H. S., \& Lee, J. Y. (2009). Receptive \& expressive vocabulary test (REVT). Seoul: Seoul Community Rehabilitation Center.

Ko, S., Choi, K. S., \& Hwang, M. (2010). Comprehension of ambiguous words in children with poor reading comprehension. Korean Journal of Communication Disorders, 15(3), 348-356.

Kwak, S. S., Hwang, B. Y., \& Jung, K. H. (2015). A study of the homonym comprehension ability of students from multicultural families according to task presentation and social cultural context. Journal of Speech-Language \& Hearing Disorders, 24(4), 379-390.

Lee, S., \& Lee, H. R. (2006). Lexical ambiguity comprehension of Korean children with specific language impairments. Korean Journal of Communication \& Disorders, 11(1), 14-29.

Lee, S., \& Lee, H. R. (2007). Definitional category analysis of ambiguous words in Korean children with specific language impairment. Journal of Speech and Hearing Disorders, 16(4), 1-18.

Lee, Y. (2011). The relationships among language, communicative abilities and motor, cognitive, and socio-emotional development in toddlers with language delays. Korean Journal of Communication \& Disorders, 16(1), $1-12$.

Mayberry, R. I., \& Nicoladis, E. (2000). Gesture reflects language development: evidence from bilingual children. Current Directions in Psychological Science, 9(6), 192-196.

Ministry of Education and Science Technology. (2013). Nuri course explanation book 3-5 years old age. Sejong: Author.

Moon, E. (2010). The ability of lexical ambiguity comprehension in 3 and 6 grades (Master's thesis). Dankook University, Yongin, Korea.

Park, H. (2013). Comparison on iconic gesture comprehension and production characteristics of 3-5 years old children with typical development and child with mild intellectual disabilities (Doctoral dissertation). Ewha Womans University, Seoul, Korea.

Peters, A. M., \& Zaidel, E. (1980). The acquisition of homonymy. Cognition, $8(2), 187-207$.

Shin, Y. (2011). Homonyms comprehension of children with cochlear implants in sentence reading (Master's thesis). Dankook University, Yongin, Korea.

Smith Cairns, H., Waltzman, D., \& Schlisselberg, G. (2004). Detecting the ambiguity of sentences: relationship to early reading skill. Communication Disorders Quarterly, 25(2), 68-78.

Um, A. (2013). The comprehension ability of lexical ambiguity in children with mild mental retardation (Master's thesis). Dankook University, Yongin, Korea.

Wankoff, L. S., \& Smith Cairns, H. (2009). Why ambiguity detection is a predictor of early reading skill. Communication Disorders Quarterly, 30(3), 183-192. 
Hee Kwon, et al. • The Homonyms Comprehension and Production in Preschool Children

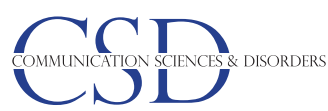

Appendix 1. 선정된 동음이의어 어휘

\begin{tabular}{|c|c|}
\hline 어휘 & 내용 \\
\hline \multirow[t]{2}{*}{ 눈 } & 뇌에 시각을 전달하는 감각 기관. \\
\hline & 대기 중의 수증기가 얼어서 땅 위로 떨어지는 흰색 결정체. \\
\hline \multirow[t]{2}{*}{ 다리 } & 사람이나 동물이 서거나 걷거나 뛰는 일을 맡는 부분. \\
\hline & 물이나 장애물을 건너갈 수 있도록 연결한 구조물. \\
\hline \multirow[t]{2}{*}{ 밤 } & 해가 진 뒤부터 동이 트기 전까지의 동안. \\
\hline & 밤나무의 열매. \\
\hline \multirow[t]{2}{*}{ 배 } & 사람이나 물건을 싣고 물 위를 떠다니도록 만든 물건. \\
\hline & 배나무의 열매. \\
\hline \multirow[t]{2}{*}{ 벌 } & 벌목에 속한 곤충. \\
\hline & 잘못을 하거나 죄를 지은 사람에게 그 대가로 주는 제재. \\
\hline \multirow[t]{2}{*}{ 쓰다 } & 사람이 모자를 머리에 얹어 덮다. \\
\hline & 사람이 물건을 어떤 일을 하는 데 도구나 수단으로 다루다. \\
\hline
\end{tabular}

Appendix 2. 동음이의어 이야기 및 그림 자료의 예

동음이의어 '눈'

\begin{tabular}{lcl}
\hline 어휘 & 순번 & \multicolumn{1}{c}{ 내용 } \\
\hline 눈 & 1 & 친구가 병원에 갔어요. \\
& 2 & 친구의 눈이 아파요. \\
& 3 & 하늘에서 눈이 내려요. \\
& 4 & 친구는 눈을 비비고, 하늘에 내리는 눈을 봐요. \\
\hline
\end{tabular}

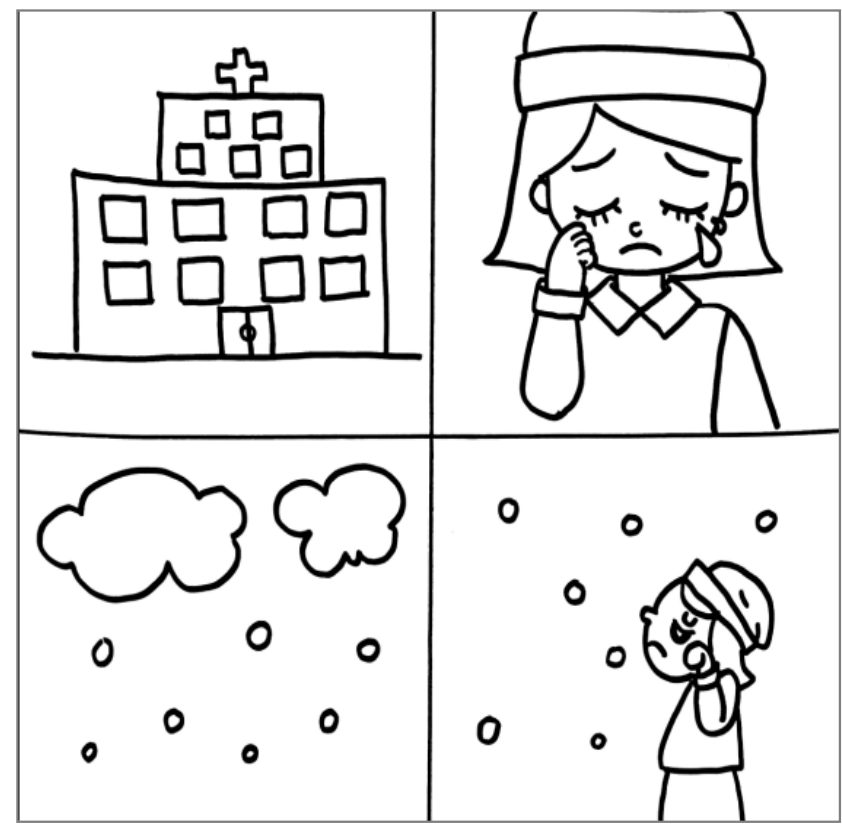

Appendix 3. 시도 및 시도 성공 기준에 대한 조작적 정의

\begin{tabular}{|c|c|c|}
\hline & & 정의 \\
\hline \multirow[t]{7}{*}{ 시도 기준 } & 시도로 간주한 상황 & 보조자의 유도 질문에 아동이 이해한 동음이의어 모호성 해결에 대한 정보를 제공한 경우. \\
\hline & 시도로 간주하지 않은 상황 & 아동이 시도성공으로 간주된 상황에서 검사가가 추가적인 정보를 요구한 상황에서 정반응한 경우. \\
\hline & & 아동이 간투사를 사용한 경우(예: 음). \\
\hline & & 아동이 보조자의 질문을 되묻는 경우(예: 뭐라고요?, 다른 밤이요?) \\
\hline & & 아동의 발음이 정확하지 않아 검사자가 되물어 다시 대답한 경우. \\
\hline & & 검사자가 추가적인 정보를 요구한 상황에서 ‘응/아니’ 등 단답으로 대답한 경우. \\
\hline & & 동음이의어의 대상이 같은 것인지 아닌지를 묻는 질문에 ‘네/아니요’로 대답한 경우. \\
\hline \multirow[t]{6}{*}{ 시도 성공 기준 } & 시도 성공 & $\begin{array}{l}\text { 검사자의 질문에 두 가지 또는 한 가지의 대상을 설명하였을 경우(예: 하나 쓴 거는 모자 쓴 거고, 다른 쓴 거는 축하해 } \\
\text { 쓴 거예요). }\end{array}$ \\
\hline & 시도 실패 & ‘몰라요’로 대답한 경우(예: 몰라요). \\
\hline & & 이름이 같다고 대답한 경우(예: 이름이 똑같아요). \\
\hline & & 아동이 그림을 Pointing한 경우(보조자는 그림을 볼 수 없으므로 실패시도로 간주). \\
\hline & & $\begin{array}{l}\text { 해결한 과제에 대해 나열하는 경우(예: ‘타는 배’로 한 가지의 동음이의어를 해결한 후, ‘수륙양용배, 경찰배, 소방배’ 등 } \\
\text { 으로 재나열한 경우). }\end{array}$ \\
\hline & & 해결한 과제를 반복하여 설명하였을 경우. \\
\hline
\end{tabular}




\section{국문초록}

\section{학령전기 아동의 동음이의어 모호성 해결 특성}

\section{권 희 · 정경희}

용인대학교 재활복지대학원 언어치료학과

배경 및 목적: 본 연구는 3-5세 아동들을 대상으로 동음이의어 모호성 해결력 차이를 알아보고자 하였다. 방법: 연구대상은 3-5세 아 동으로 연령집단 간 10 명씩 총 30 명으로 정상발달로 보고된 아동이며, 수용어휘력이 정상발달을 보이는 아동이다. 연구의 과제는 동음 이의어가 대립된 한 문장을 포함한 4 컷의 그림으로 구성하였다. 검사자가 아동에게 그림을 제시하며 이야기를 설명해 주고, 아동이 보 조자에게 다시 이야기를 해 주었다. 결과: 동음이의어 모호성 이해수는 3 세와 5 세, 4 세와 5 세 집단 간 유의한 차이가 있었다. 동음이의 어 모호성 해결 수에서도 3 세와 5 세 집단, 4 세와 5 세 집단에 유의미한 차이가 나타났다. 동음이의어 모호성 해결 총 시도수에서 3 세와 5 세 집단, 4 세와 5 세 집단 사이에 유의미한 차이가 나타났으며, 동음이의어 모호성 해결성공률에서도 3 세와 5 세 집단, 4 세와 5 세 집단에 유의미한 차이가 나타났다. 동음이의어 모호성 해결유형 중 구어해결률에서 3 세와 5 세 집단, 4 세와 5 세 집단에 유의미한 차이가 나타 났으나, 구어+제스처 해결률에서는 유의미한 차이가 나타나지 않았다. 구어+제스처 해결 시 사용한 제스처 유형 중 지시적·도상적 제 스처 두 유형 모두 집단 간 유의미한 차이가 나타나지 않았다. 논의 및 결론: 위의 결과로 보아, 동음이의어 모호성 이해와 해결에 4-5세 에 발달하는 것임을 알 수 있었다. 동음이의어 모호성 총 시도수와 해결성공률의 측면에서는 연령이 늘어남에 따라 시도수는 줄어들 고, 해결성공률이 높아짐을 알 수 있었다.

핵심어: 동음이의어, 어휘적 모호성, 지시적 제스처, 도상적 제스처

본 논문은 제1저자의 석사학위논문을 수정·보완하였음.

\section{참고문헌}

강은선(2018). 1,3,5학년 일반아동의 초등학교 고빈도 다의어 이해 연구. 용인대학교 대학원 석사학위논문.

강희정, 황민아, 임종아(2013). 읽기이해부진아동의 동음이의어 이해 능력. 학습장애연구, 10(2), 167-176.

고선희, 최경순, 황민아(2010). 읽기이해부진아동의 다의어 의미 처리 특성. 언어청각장애연구, 15(3), 348-356.

곽신실, 황병용, 정경희(2015). 과제제시 및 사회·문화적 맥락 조건에 따른 다문화가정 아동의 동음이의어 이해. 언어치료연구, 24(4), 379-390.

교육과학기술부(2013). 3-5세 연령별 누리과정 해설서. 세종: 교육과학기술부.

김승희(2010). 초등학교 저학년 읽기부진 아동들의 동음이의어 과제를 이용한 모호성 문장 이해능력. 이화여자대학교 대학원 석사학위논문.

김영태, 홍경훈, 김경희, 장혜성, 이주연(2009). 수용·표현어휘력검사(REVT). 서울: 서울장애인종합복지관.

김하나(2014). 학령기 경도지적장애 아동의 참조적 의사소통에서 산출되는 제스처 특징. 단국대학교 대학원 석사학위논문.

김현영(2014). 초등학교 저학년 아동의 어휘적 중의성 이해능력. 대구대학교 대학원 석사학위논문.

문은란(2010).3,6학년 아동의 어휘적 중의성 이해 능력. 단국대학교 대학원 석사학위논문.

박현주(2013). 3-5세 일반아동과 경도지적장애아동의 도상적 제스처 이해 및 표현 특성 비교. 이화여자대학교 대학원 박사학위논문.

신윤경(2011). 문장읽기과제로 살펴본 인공와우 아동의 동음이의어 이해. 단국대학교 대학원 석사학위논문.

안소정, 방희정, 이순행(2010). 문법형성단계 2-3세 아동의 세부 몸짓 사용 비율의 변화: 사상적 몸짓을 중심으로. 한국심리학회지: 발달, 23(1), 33-50.

엄애경(2013). 경도지적장애아동의 어휘적 중의성 이해 능력. 단국대학교 대학원 석사학위논문.

이승복, 이희란(2006). 단순언어장애아동의 어휘적모호성 이해. 언어청각장애연구, 11(1), 14-29.

이승복, 이희란(2007). 단순언어장애아동의 단어정의하기: 정의유형 분석을 중심으로. 언어치료연구, 16(4), 1-18.

이윤경(2011). 언어발달지체 영유아의 언어 및 의사소통능력과 인지, 운동 및 사회성 발달과의 관계. 언어청각장애연구, 16(1), 1-12. 
장보아(2000). 동음이의어와다의어의 구분기준에 관한 고찰: 실제 자료군(corpus)의 적용·분석. 경희대학교 대학원, 석사학위논문.

장종윤, 정미란, 황민아(2014). 초등학교 저학년 다문화가정 아동의 동음이의어 이해와 정의하기. Communication Sciences \& Disorders, 19(1), 71-

79.

조희은(2006). 청각장애아동의 다의어 이해와 유형 분석. 단국대학교 대학원, 석사학위논문.

\section{ORCID}

권 희(https://orcid.org/0000-0001-5035-0314); 정경희(https://orcid.org/0000-0002-1816-0171) 